Justyna Dąbkowska-Kujko

https://orcid.org/oooo-oooI-9873-5555

Katolicki Uniwersytet Lubelski Jana Pawła II

\title{
Staropolski przekład dzieła Lingua Erazma z Rotterdamu w „teatralnym lustrze” pierwowzoru (casus jednego wątku)
}

Artykuł jest próbą spojrzenia na staropolskie strategie translatorskie w świetle oceny wczesnorenesansowej pracy przekładowej anonimowego tłumacza jednego z mniej znanych dzieł Erazma z Rotterdamu pt. Lingua. Treść rozprawy koncentruje się nie tylko na wskazaniu i omówieniu metod tłumaczenia, ale przede wszystkim odsłonięciu na przykładzie jednego zaledwie wątku sposobów myślenia obu autorów, estetyki słowa, kultury i pragmatyki transponowania zasobów erudycyjnych, wreszcie - dialogu międzykulturowego, jaki bez wątpienia otwiera każda konfrontacja oryginału z przekładem.

The study attempts to look at Old Polish translation strategies in the light of the evaluation of the early Renaissance translation work by an anonymous translator of one of Erasmus' lesser-known works, Lingua. The article focuses not only on indicating and discussing the methods of translation, but above all on revealing - on the example of one plot - the thinking procedures of both authors, the aesthetics of words, the culture and pragmatics of transposing erudite resources, and finally - the intercultural dialogue that undoubtedly opens up every confrontation of the original with translation.

Słow a kluczowe: przekład, oryginał, język, retoryka, aktor, teatr, dramat, hipokryzja

Ke y w o rd s: translation, original, language, rhetoric, actor, theatre, drama, hypocrisy 
Przetłumaczone przez Anonima (a przekładane też na wiele innych europejskich języków, m.in. na niemiecki, flamandzki oraz hiszpański), po czym wydane w krakowskiej oficynie Hieronima Wietora w 1542 r. $^{1}$ dzieło Lingua (1525) ${ }^{2}$ Erazma z Rotterdamu jest swoistego rodzaju fenomenem sztuki translacji i sztuki słowa u progu rozwoju literatury Pierwszej Rzeczypospolitej. Choć mimo przeprowadzonych badań oraz postawionych hipotez nie udało się wiarygodnie ustalić, kim jest autor tego wczesnego tłumaczenia, jaki jest jego estetyczny i kulturowy status ${ }^{3}$, a znajomość i oddziaływanie literackie czy ideowe jego pracy niemal wcale nie zostało poświadczone w piśmiennictwie epok dawnych (analogicznie jak i samo dzieło Lingua nigdy nie stało się tak ważne i popularne jak np. Moriae encomium z 1511 r.), z całą pewnością możemy rzec, iż polska postać Erazmowego utworu należy do bardzo wczesnego okresu kształtowania się staropolskiej prozy, wciąż mało samodzielnej pojęciowo, chętnie zaś kalkującej i wykorzystującej rekwizytornię terminologii wypracowanej w laboratoriach łacińskiej szkoły retorycznej. Dzieło to - oprócz centralnej dla renesansowej kultury problematyki języka postrzeganego z perspektywy antropologii humanistycznej, a nawet filozofii czy etyki mowy oraz społecznej komunikacji - w wymiarze czysto językowym obrazuje proces konstytuowania się literackiej polszczyzny, wznoszenia i utrwalania jej estetycznych norm, jest też świadectwem wymagającej dużej wrażliwości i roztropności konfrontacji z osobliwą łaciną pierwowzoru $-\mathrm{z}$ jednej strony konwersacyjnie swobodną, sugerującą prostotę, z drugiej erudycyjną i aluzyjną, teatralną niemal, wieloznaczną, zmetaforyzowaną i obrazową, często ironiczną bądź zaprawioną groźnym, jeśli nie po prostu miażdżącym sarkazmem ${ }^{4}$.

Fakt, że nie wiemy, kim był tłumacz Erazmowego dzieła, znacznie utrudnia ocenę przekładu. Nie pozostawił on bowiem żadnej odautorskiej wskazówki pozwalającej zrozumieć i rozpoznać jego stosunek do pierwowzoru. Obie przedmowy, które otwierają polską postać dzieła,

1 Księgi, które zowa Język, z tacińskiego na polski wytożony, Kraków 1542.

2 Desiderius Erasmus Roterodamus, Lingua. Opus novum et hisce temporibus aptissimum, Basileae 1525 .

3 Na temat dociekań atrybucyjnych związanych z osobą Stanisława Łaskiego szerzej zob. J. Dąbkowska-Kujko, Wprowadzenie do lektury, w: Erazm z Rotterdamu *Anonim, Księgi, które zowa Język, wyd. J. Dąbkowska-Kujko, Warszawa 2019, s. 22-25. Wszystkie cytaty z tłumaczenia podawane są za tą edycją.

4 Por. ibidem, s. 25 nn. 
nie pochodzą od autora translacji ${ }^{5}$, toteż nie podejmują problemów teorii przekładu, tym bardziej nie ujawniają zasad pracy z podstawą łacińską. Wszystko zatem, czego możemy dowiedzieć się o tłumaczu i jego warsztacie pisarskim, znaleźć możemy wyłącznie w samym tekście dzieła. Utwór ten wszakże nie tylko „opowiada” swoją historię „wyradzania się” z łaciny, ale i na swój sposób uobecnia też tłumacza, który - bez nazwiska wprawdzie - jawi się niemal osobowo w literze, słowie, zdaniu, w języku, poprzez który możemy rozpoznać $\mathrm{z}$ jednej strony wartościowy i istotny składnik translacyjnego compositum, z drugiej - kulturowy czy ideowy horyzont staropolskiego autora przekładu.

Siłą rzeczy bowiem wydany jest tłumacz - dowodził Leonardo Bruni - na łup stylu wypowiedzi tego, kogo tłumaczy, i tylko wówczas będzie mógł dobrze zachować sens, gdy sam wejdzie i wplecie się w jego zawiłe okresy, a zarazem we właściwe znaczenia słów poszczególnych i w ogólny obraz stylu. To jest najlepsza metoda przekładu: zachować postać stylistyczną oryginału tak, aby mu nie zabrakło wdzięku i piękna. [--] Tłumacz musi rozpoznać tego rodzaju, że tak powiem, moce prozy i pokazać je również w języku, na który przekłada. Istnieją dwa rodzaje ozdob: jedne nadają barwę słowom, drugie - myślom $^{6}$.

Z góry chyba możemy założyć, że tak wczesna praca translatorska, jaką są Księgi, nie zmieściłaby się w kanonie oczekiwań humanisty włoskiego, który nie myślał nawet o jakichkolwiek próbach stylistycznego przestrojenia oryginału, o tendencjach adaptacyjnych, zabiegach redukcyjnych, banalizacjach semantycznych i retorycznych, abundancjach, redundancjach czy amplifikacjach leksykalnych, świadomych opustkach, a w szczególności - o „banicjach” erudycyjnych. I choć ów rejestr, odnoszący się oczywiście do staropolskiego przekładu, bo wszystkie te strategie można właśnie tam znaleźć, mógłby sugerować, że dzieło Erazma posłużyło Anonimowi do budowania własnego tekstu albo ściślej - do tworzenia tekstu przykrojonego na własną miarę, w istocie nie do końca tak było. Nie mamy tu do czynienia

5 Pierwszą dedykację skierował drukarz Hieronim Wietor do Jana Amora Tarnowskiego, męża Zofii Szydłowieckiej, córki Krzysztofa, któremu Erazm w 1525 r. przypisał swoje dzieło Lingua; druga jest właśnie tłumaczeniem owej dedykacji, którą Erazm skierował do kasztelana krakowskiego.

${ }^{6}$ L. Bruni, O poprawnym przektadaniu, tt. W. Olszaniec, w: Cyceron, św. Hieronim, Burgundiusz z Pizy, Leonardo Bruni, O poprawnym przektadaniu. Teksty tacińskie i przektady polskie, tł. W. Seńko, J. Domański, W. Olszaniec, wstęp J. Domański, Kęty 2006, s. 175-177. 
ani z trudem imitacyjno-emulacyjnym, ani z zasadą verbum de verbo, ani wreszcie z regułą sensum exprimere de sensu. Praca Polaka, lokując się gdzieś pomiędzy tymi znanymi od wieków wskazówkami, generuje wewnętrzne napięcie warsztatowe, odsłania prawdziwe bogactwo translatorskich strategii, a przy tym nie łamie kryterium adekwatności tłumaczenia, pozostając tłumaczeniem właśnie, nie zaś - jak chcieli niektórzy badacze - parafrazą ${ }^{7}$.

Cechą charakterystyczną dyskursu Rotterdamczyka, znakomicie zresztą realizującą się w diatrybicznej strukturze dzieła Lingua ${ }^{8}$, jest sugestywna, obrazowa i dynamiczna dystynkcja wywodu, nigdy więc niepoprzestająca na teoretycznych, abstrakcyjnych odniesieniach do sfer etycznej, teologicznej, filozoficznej, których utwór wszakże dotyczy. Cechę tę należałoby odczytywać z jednej strony jako swego rodzaju performatywność, będącą trwałą własnością mowy Erazma, a wyrażającą się w przeświadczeniu, iż język jest aktywny wobec świata, że nie tylko przedstawia rzeczywistość, ale i dynamicznie ją przeobraża; z drugiej zaś - jako postulat estetycznej reakcji na komunikaty płynące ze świata natury i kultury oraz obecność i miejsce w tym świecie człowieka. Wykorzystywanie przez Rotterdamczyka motywów literatury antycznej i mitologii poprzez transponowanie ich nie tyle na pojęcia, ile na często układane paralelnie lub zrzucane kaskadowo obrazy

7 Konkluzja M. Karplukówny po dokonaniu analitycznego zestawienia obu tekstów jest następująca: „Mimo niewątpliwych starań tłumacza, jego niezaprzeczalnego talentu literackiego, porównując tekst łaciński z wersją polską doznajemy wrażenia nużącej rozwlekłości. Składa się na nią kilka przyczyn: glosowany sposób tłumaczenia, brak polskich jednowyrazowych odpowiedników, wtrącanie w ciąg tekstu różnorodnych komentarzy: od bliższych określeń osób, miejscowości i dzieł - do formułowania dodatkowych objaśnień sensu tak, by niewprawny czytelnik dostał tekst ze wszech miar zrozumiały. Jeśli do tej dydaktyczno-popularyzatorskiej tendencji dodamy zubożenie stylu i treści oryginału, szczególnie treści, przez stałe opuszczanie fragmentów greckich, a dowolne pomijanie niektórych łacińskich zmuszeni będziemy nazwać Księgi nie przekładem, lecz parafrazą utworu Erazma z Rotterdamu”, eadem, "Lingua” Erazma z Rotterdamu w polskim przektadzie z roku 1542. Część I, „Pamiętnik Literacki”, 62, 1971, 1, s. 141. Wiele lat później, gdy uczona powróciła do przekładu dzieła Erazma, zajęła stanowisko łagodniejsze, wskazujące na to, iż właściwie wycofuje się ze swej wcześniejszej oceny; zob. eadem, Erazm w Polsce: "Lingua” w anonimowym przektadzie z 1542 r., "Język Polski”, 84, 2004, 1, s. 2-3.

8 Zob. J. Dąbkowska-Kujko, „Lingua” Erazma z Rotterdamu a diatryba, w: Stawa $z$ dowcipu sama wiecznie stoi... Prace ofiarowane Pani Profesor Alinie Nowickiej-Jeżowej z okazji pięćdziesięciolecia pracy naukowej, red. M. Hanusiewicz-Lavallee, W. Pawlak, Lublin 2018, s. 57-68. 
nie spotkało się jednak ze zrozumieniem polskiego tłumacza. Tak oto rezygnacja z wielu odniesień do kultury starożytnej stała się osobliwym paradygmatem polskiego przekładu w ogóle. O ile bowiem niderlandzki pisarz widział w tych obrazach nie tylko narzędzie retorycznej perswazji i czynnik argumentacyjny, ale również tworzywo literackiej gry wyobraźni, namnażającej coraz to nowe pola odniesień, o tyle Anonim zainteresowany był niemal wyłącznie eksplikacją sensów, które wypreparowywał z plastycznych, aluzyjnych skojarzeń Erazma i przetwarzał w pragmatyczne frazy, filtrujące wszelakie nadwyżki obrazowe.

Przez ów filtr nieczęsto przedostawały się zwłaszcza odniesienia mitologiczne 9 . „Gęsto zaludniony protagonistami i statystami grecko-rzymskiego teatru mitologicznego" 10 tekst oryginału, w przekładzie nieco „się odludnia”. Jest to dość niepokojący sygnał, tłumacz bowiem zdaje się nie uczestniczyć w procesie adaptacji pogańskiej starożytności, nie rozumieć humanistycznej idei aplikacji tradycji kulturowej antyku ${ }^{11}$, która przy pomocy narzędzi metaforycznych, symbolicznych i alegorycznych odczytań pozwalała sięgać w głąb kultury i odświeżać jej spetryfikowane akty i artefakty. Zasada łączenia starożytnych wierzeń i Pisma Świętego; spotkań realiów i mitu; mitu, literatury i nauki; nauki, filozofii, teologii i rzeczywistości naturalnym traktem wiodła z jednej strony do poszerzenia dziedziny poznawczej poprzez tradycję, pismo, wyobraźnię, obserwację, z drugiej zaś otwierała możliwość przechodzenia z kategorii czasu do kategorii przestrzeni. Dla Erazma bowiem historia języka to mirabilia mundi, jeśli nie historia naturalis, bo tak on patrzy na język i w taki sposób o nim mówi, jakby wpisywał się on w "niezwykłe dzieła natury” i zarazem w rachubę czasu, a więc w linię ciągłego chronos i akcydentalnego kairos zarazem, bo przykłady z dzieł starożytnych aktualizują się w ,jego teraźniejszości”, prowadząc zarazem do modyfikacji nieco już przykurzonej topiki. Obrazowy sposób wypowiadania się Erazma bliski jest i platonikom, i biblijnym prorokom czy językowi Ewangelii, tym samym więc dość oryginalny w dobie humanistycznych czy filologicznych upodobań do monumentalnego abstraktu.

9 Na fakt usuwania przez Anonima imion bóstw mitologicznych zwróciła już uwagę M. Karplukówna, "Lingua” Erazma z Rotterdamu w polskim przektadzie, s. 138.

10 Wyrażenie zapożyczone z: L. Marinelli, Polski „Adon”. O poetyce i retoryce przekładu, tł. L. Marinelli, A. Nowicka-Jeżowa, współudz. Z. Ożóg, Izabelin 1997, s. 77.

11 A był to wszakże czas sprzed Bibliotheca selecta de ratione studiorum Antonia Possevina (1573). 
Kultura intelektualna Erazma wyraźnie przerosła horyzont ideowy tłumacza, dla którego już choćby mitologia zdaje się być obszarem wyłącznie otwierającym okazje do przyswajania pogańskich struktur myślenia, a aluzje do kultury antycznej - balastem naruszającym powagę chrześcijańskich aksjomatów. Tam tylko, gdzie to możliwe, konsekwentnie i sumiennie banalizuje oraz redukuje aluzje do kultury antycznej, usuwa też mitologiczne świadectwa z przekładanego przez siebie dzieła. Postępuje tak, a to poszukując dla starożytnych odniesień alternatyw językowych (trzeba przyznać, że wówczas zwykle utrzymuje semantyczną dykcję wzoru, ale gubi za to retoryczną ekspresję, dyskursywny, erudycyjny czy wizualny walor tekstu):

Ate est Lingua, si careat gubernatore, copiae cornu est, si recte utaris. Eris est iurgiorum excitatrix, sed eadem est Gratia benevolentiae conciliatrix. Erinnys est omnium malorum invectrix, sed eadem tranquillat omnia ${ }^{12}$.

Język pobudza swady, ale tenże zasię jedna łaskę i przyjaźń ludską; ten pobudza wszytki złe rzeczy, tenże zasię pokoi wszytko" ${ }^{13}$,

a to ograniczając mitologiczną wzmiankę do niezbędnego dla utrzymania sensu minimum:

Apud priscos obtinebat olim religiosa consuetudo, ut pueri qui vellent iurare per Herculem, non sinerentur id facere sub tecto, sed iubebantur ire sub dium, ut vel hac mora discerent iurare parcius ac circumspectius. Sic enim publicum morem interpretati sunt viri sapientes. Quidam addunt ipsum Herculem ad ius iurandum fuisse religiosissimum ac verecundissimum, adeo ut per omnem vitam, non nisi semel iuraverit, idque soli Phyleo Augeae filio. Hoc exemplum ut posteris commendaretur aiunt Pythiam hoc iuris iurandi genus proposuisse Lacedaemoniis, addens esse satius si citra ius iurandum affirmarent. Nos vel ad aras iuramus per Christum, non modo sub tecto per Herculem ${ }^{14}$.

12 Wszystkie cytaty z dzieła łacińskiego Erazma z Rotterdamu przywołuję za wydaniem: Desiderius Erasmus Roterodamus, Lingua. Opus novum et hisce temporibus aptissimum, Cracoviae 1526 (dalej: Erasmus Roterodamus, Lingua 1526), k. 93ver. Tł. „Język jest Ate [boginią zaślepienia], jeśli mu brak sternika, jest rogiem obfitości, jeżeli używasz go właściwie. Jest Eris [boginią sporów], inspiratorką kłótni, ale tenże jest też Gracją, pojednawczynią dobrej woli. Jest Erynią [boginią zemsty], wynalazczynią wszelkiego zła, ale tenże uspokaja też wszystko". Jeśli nie zaznaczono inaczej, wszystkie tłumaczenia tekstów źródłowych pochodzą od autorki artykułu.

13 Erazm z Rotterdamu *Anonim, Ksiegi, IV 190, s. 152.

${ }_{14}$ Erasmus Roterodamus, Lingua 1526, k. 65ver. Tł. „U starożytnych utrzymywał się niegdyś religijny zwyczaj, by chłopcom, którzy chcieliby przysięgać na Herkulesa, nie pozwalano czynić tego [od razu] pod dachem, ale kazano im wychodzić 
Za starych ludzi, gdy kto przysiąc miał przez imię Herkulesowe, którego za boga chwalili, tedy tego pod dachem uczynić nie mogli, jedno wyszedszy, aby tym opatrniej a nieczęściej ludzie na przysięgę się kwapili ${ }^{15}$,

a to wreszcie nie tylko skracając i upraszczając przekładany passus łaciński, ale też odrzucając wszystkie odniesienia czy aluzje do literatury oraz kultury antycznej, a wraz z nimi erudycję, retoryczną ekspresję, dowcip:

An isti metuant peierare, si qua sollicitet utilitas, cum citra ullam necessitatem aut commodi spem quotidie deierent? Exsibilatur in ethnicorum theatris

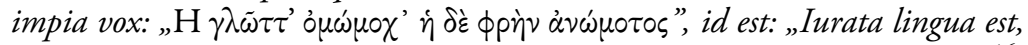
animus iniuratus est" [EURIP. Hipp. 612; por. ARISTOPH. Ran. 1471] ${ }^{16}$. Quin potius exploditur e vita Christianorum? Ridetur in Plautinis fabulis leno periurus, linguam habens qui rem solveret omnibus [PLAUT. Capt., prol. 57], cur inter Christianos in pretio sunt qui idem faciunt quod leno? Olim in ludum vertebatur Venereum ius iurandum [Ov. Am. 2,7,27-28; 8,18-20; por. HOR. Carm. 2,7,25-26; PLAUT. Asin. 905-906; SUET. Vit.caes. Aug. 71,2; oraz ER. Ad. I 2,13[113]: Si crebro iacias, aliud alias ieceris], nunc fere pro ludo ducitur omne ius iurandum sollemne, veluti quod iurat princeps populo, quod in scholis professionem septem artium liberalium suscipientes non satis liberaliter iurant ex more potius quam ex animo ${ }^{17}$.

pod gołe niebo, aby przez tę zwłokę uczyli się przysięgać rzadziej i z większą rozwagą. W ten bowiem sposób ludzie mądrzy wyjaśnili ten publiczny zwyczaj. Niektórzy dodają, że sam Herkules do tego stopnia miał nader bogobojne i przezorne nastawienie do przysięgi, że przez całe życie złożył przysięgę tylko jeden raz i to jedynie Fyleusowi, synowi Augeasza. Powiadają, że Pytia, by przykład ten polecić potomnym, taki sposób przysięgania zaproponowała Spartanom, dodając, że wystarczy, jeśli będą raczej poręczać bez składania przysięgi. My zaś nawet przy ołtarzach przysięgamy na Chrystusa, cóż dopiero pod dachem na Herkulesa”.

15 Erazm z Rotterdamu *Anonim, Księgi, IV 52, s. 117.

16 Jeśli nie zaznaczono inaczej, wszystkie komentarze w cytowanych źródłach pochodzą od autorki artykułu.

17 Erasmus Roterodamus, Lingua 1526, k. 65rec. Tł. „A czyż tacy mają lękać się krzywoprzysięgać, jeżeli do tego pobudza korzyść, gdy codziennie przysięgają bez żadnej konieczności albo nadziei zysku? W teatrach pogan wygwizduje się bezbożną sentencję: "Język przysięgał, nie przysięgło serce«. Dlaczego raczej nie wypędza się tego gwizdami z życia chrześcijan? W sztukach Plauta wyśmiewany jest krzywoprzysiężny stręczyciel posiadający język, którym potrafiłby wszystkim załatwić sprawę; dlaczego pomiędzy chrześcijanami są w cenie ci, którzy postępują jak ten stręczyciel? Niegdyś w drwinę obracano przysięgę na Wenerę, obecnie niemal jako drwinę traktuje się każdą uroczystą przysięgę, na przykład, co przysięga władca ludowi, co w szkołach podejmujący w sposób niezbyt wyzwolony stanowisko wykładowcy siedmiu sztuk wyzwolonych, przysięgają raczej według zwyczaju niż z serca”. 
Jakoż takowi mają się bać przysiąc, gdyby im to jaki pożytek niosło, którym to już weszło w obyczaj, iż oprócz też potrzeby albo pożytku przysięgają ustawicznie? I weszła przysięga w obyczaj, że w napoważniejszych rzeczach, jako gdy król albo książę przysięga poddanym, tak też i w innych rzeczach nie z umysłu przysięgę czynią, aby się temu dosyć zstać miało, tylko aby się obyczajowi dosyć zstało ${ }^{18}$.

Jest jeszcze jedna osobliwość przekładu: brak w nim choćby śladu nawiązań do teatru, przywoływanego $\mathrm{w}$ oryginale zarówno wprost w formie cytatu „zdjętego” z desek sceny greckiej, jak i za sprawą bezpośrednich odniesień do łacińskich komedii Plauta i Terencjusza. Że Anonim treści sceniczne usuwał intencjonalnie i konsekwentnie, pokazują liczne fragmenty Ksiąg, większości z nich nie znajdziemy bowiem w żadnym miejscu tłumaczenia.

Charakterystyczny dla humanistycznego piśmiennictwa filozoficznego, satyrycznego czy politycznego oraz dla dydaktycznie obciążonej literatury społecznej motyw aktora i aktorstwa, spowijający przecież wiele, nie tylko Erazmowych, wypowiedzi, jest częścią prowadzonych ówcześnie rozważań nad istotą człowieczych wartości, jest ważnym komponentem rozwiniętej uczonej debaty nad rolą dysymulacji i stwarzania pozorów zarówno w życiu społecznym, jak i w sztuce rządzenia państwem ${ }^{19}$. Uwagę tę potwierdza aktualność rozbudowania tego wątku zarówno w Księciu Machiavellego czy w dziełach Morusa (Utopia, Historia króla Ryszarda III) ${ }^{20}$, jak i we wszystkich tych renesansowych pracach, które konstytuują wątek theatrum mundi / vitae humanae $^{21}$, a to sięgających po tradycję stoicką, neoplatońską czy

18 Erazm z Rotterdamu *Anonim, Ksiegi, IV 51, s. 117.

19 Zob. I. Kąkolewski, Melancholia wtadzy. Problem tyranii w europejskiej kulturze politycznej XVI stulecia, Warszawa 2007.

20 Idem, W poszukiwaniu "makiawelskiego momentu”. Metafora księcia jako wielkiego symulanta i aktora u Niccolò Machiavellego i Tomasza Morusa, "Przegląd Historyczny", 96, 2005, 2, s. 305-325.

21 Począwszy od Vivesowej Fabula de homine (zob. L. Vives, Bajka o cztowieku, w: idem, O podawaniu umiejętności, tł., wstęp i przyp. A. Kempfi, Wrocław 1968, s. 340-346), na De constantia (II 11) i Politicorum libri (IV 14) Lipsjusza kończąc. Na temat wątku theatrum mundi w literaturze i kulturze doby wczesnonowożytnej zob. m.in. E. R. Curtius, Literatura europejska i tacińskie średniowiecze, tł. i oprac. A. Borowski, Kraków 1997, s. 147-153; J. Kotarska, Topos "theatrum mundi" w poezji przetomu XVI i XVII wieku, w: Przetom wieków XVI i XVII w literaturze i kulturze polskiej, red. B. Otwinowska, J. Pelc, Wrocław 1984, s. 145-169; eadem, "Jesteśmy jakby na gre persony ubrane..." Barokowe wersje toposu theatrum mundi, w: eadem, Theatrum mundi. Ze studiów 
patrystyczną, a to realizujących zróżnicowane genologicznie formy satyryczne, z Erazmowym adagium Sileni Alcibiadis i może zwłaszcza Moriae encomium $^{22}$ na czele. Ow stary - bo mający Platońskie korzenie, a kontynuację m.in. w greckich dialogach Lukiana oraz łacińskich Cycerona czy Seneki, a potem np. w Policraticusie Jana z Salisbury motyw okazał się szczególnie ważny dla Rotterdamczyka, stając się częścią jego filozofii człowieka, człowieka „nagiego”, nieosłoniętego pozorami, obywającego się bez obłudy, a więc takiego, którego wartość mierzalna jest wartością przyległości mowy i czynu, którego mowa ma wartość czynu i jako taka daje się nie tylko poznać, ale i zrealizować $\mathrm{w}$ ewangelicznej z ducha przestrzeni christianitas. W ten sposób Erazm występował przeciw - coraz bardziej zyskującym uznanie i coraz odważniej postulowanym we wczesnonowożytnym piśmiennictwie politycznym ${ }^{23}$ - koncepcjom dysymulacji, mistyfikacji, obłudy ${ }^{24}$, uaktywnianym zwłaszcza w życiu społecznym na wszystkich szczeblach osobowych relacji. Sytuując zresztą swe dzieło w przestrzeni charakterystycznej dla skrajnej parenezy i zarazem przybierając postawę bezwzględnego krytyka, Rotterdamczyk zazwyczaj wcale nie widział w przebiegłości czy hipokryzji sztuki, do opanowania i uprawiania której - jak sądzono - potrzebne jest bezcenne ingenium, ale raczej antytezę szlachetnej prostoty i szczerości. Wątek teatru zatem stał się dla niego narzędziem, przy pomocy którego rozprawiał się z tematem potwarzy i fałszu, które wślizgnęły się per universam dicionem Christianam $^{25}$ („wszędzie tam, gdzie panuje chrześcijaństwo”).

nad poezja staropolska, Gdańsk 1998, s. 5-42; M. Sznajderman, Btazen. Maski i metafory, Gdańsk 2000, zwł. s. 45-66. Metaforze życia-teatru poświęciła swoją pracę i wszechstronnie omówiła zagadnienie L. G. Christian: Theatrum mundi. The History of an Idea, New York-London 1987.

22 Zob. Erazm z Rotterdamu, Pochwata gtupoty, tł. E. Jędrkiewicz, Warszawa 2001, s. 61. Na temat wątku teatralizacji w pismach Rotterdamczyka por. Z. Szmydtowa, Funkcja stylu w teorii i w praktyce autorskiej Erazma, w: eadem, O Erazmie i Reju, Warszawa 1972, s. 70-71.

23 Choć czas prawdziwego i pełnego rozwoju motywu teatru w odniesieniu do koncepcji politycznych przypadnie dopiero na drugą połowę wieku XVI (zwłaszcza prace Justusa Lipsjusza) i na stulecie XVII (m.in. słynne dzieło Fajardo Diego de Saavedry Idea principis christiano-politici centum symbolis expressa czy Ambrożego Marlianiego Theatrum politicum in quo quid agendum sit a principe, et quid cavendum, accurate praeseribitur).

24 Sprzeciw wobec „teatralizacji” życia politycznego wyraził Erazm zwłaszcza w dziele Institutio principis Christiani.

25 Erasmus Roterodamus, Lingua 1526, k. 83ver. 
Jeśli uświadomimy sobie, że to właśnie hipokryzja jest jedną z kilku negatywnych bohaterek dzieła Lingua i wyszukamy w tekście ów fragment, gdzie Erazm wykorzystuje dwuznaczność wyrazu hypocrites (III 136-137) - w języku greckim (írokpırńs) odsyłającego do pojęcia aktora, przenośnie natomiast oznaczającego kogoś, kto odgrywa cudzą rolę („obłudnik”) 26 - zrozumiemy konsekwencje redukcji dokonywanych w polskim utworze przez Anonima. Redukcje te wynikały często nie tyle z chęci adaptacji czy akomodacji tekstu łacińskiego do kulturowych uwarunkowań Rzeczypospolitej, ile ze zwykłego zniecierpliwienia bądź (co bardziej prawdopodobne) z braku świadomości, co dla przekazu Rotterdamczyka ma znaczenie ideowe i jest wyrazem swoiście chrześcijańskiego etosu, albo który zwrot czy motyw ma ciężar eksplikatywny i udobitniający, który zaś wyłącznie ornamentacyjny. Staropolski tłumacz bardzo konsekwentnie więc unika wyrażeń konotujących widowiskowość czy teatralność (theatricum), zwłaszcza zaś słów „aktorstwo”, „komedia”, „sztuka teatralna”27 (zastępuje je wyrazem „błazeństwo”) tam, gdzie Erazm wyraźnie nie tylko ujawnia, ale i prowadzi semantyczną grę między wyrazami hypocrites i histrio po to, by wyrazić myśl o świecie przeżartym obłudą, by powiedzieć, że to, co już za czasów starożytnych zostało zdiagnozowane jako występne i wyrugowane z życia społecznego, w jego czasach wraca w chwale i occupat omnes orbis honores („zajmuje wszystkie światowe godności”), że człowiek jest aktorem zarówno w polityce, jak i w życiu zakonnym, prywatnym, małżeńskim, bez przerwy więc odgrywa jakieś teatralne/tandetne role:

Ridentur mulierculae quae fucis pingunt faciem suam, sed magis rideantur viri, si subinde sumant aliam personam, et nunc senes, nunc iuvenes, nunc rubicundi, nunc pallidi, nunc obesi, nunc graciles prodeant in forum. At istiusmodi sunt, quorum oratio dissidet ab animo. Et hoc histrionum genus nemo miratur, nullus explodit ${ }^{28}$.

26 Zob. Erazm z Rotterdamu *Anonim, Ksieggi, Objaśnienia, s. 435.

27 Raz tylko w całym przekładzie za oryginałem Anonim powtórzył słowo „teatr” i to w łacińskim brzmieniu (ibidem, III 112, s. 96): „do theatrum pałacu, gdzie igry bywały”, nie darując sobie przy tym objaśniającej amplifikacji, jakby czytelnik miał nie wiedzieć, co to jest ów teatr, w Erazmowej podstawie (Erasmus Roterodamus, Lingua 1526, k. 48rec.) bowiem w tym miejscu mamy zaledwie in theatrum (,w teatrze”).

28 Erasmus Roterodamus, Lingua 1526, k. 60ver.-61rec. Tł. „Wyśmiewa się kobietki, które szminkami malują swoje twarze, ale jeszcze bardziej wyśmiewano by mężczyzn, gdyby przybierali coraz to inną postać i pojawialiby się na forum to jako 
Utraciwszy obrazowe i dowcipne szczegóły, wyhamowawszy dynamikę teatralnych metamorfoz scenicznych, wyciszywszy gwizdy publiczności, passus ów pod piórem Anonima wypełniają już tylko ospałe amplifikacje leksykalne i redundancje semantyczne. Likwidacja humorystycznego tonu obrazowej funkcjonalizacji tekstu prowadzi prostym traktem do swoistej banalizacji na wszystkich piętrach retorycznej ekspresji:

Niewiasty, które twarz malują, bywają pośmieszne w tym od innych, eż się chcą inaksze uczynić niżli są. Mężczyzny, którzy by chcieli tak twarz sobie odmieniać, jeszcze by pośmieszniejszy byli. Cóż ci a takowi nie mają być za lekkie a za pośmienie miani, którzy w tym się odmieniają a inakszy się ukazują w mowie swej niżli są na duszy a na myśli swojej?22.

Tłumacz objaśnia to, co oczywiste (dlaczego kobiety nakładają na swe twarze makijaż), skraca i przekształca to, co odsyła do scenicznych tradycji antycznego teatru (mężczyźni biegający po forum i odmieniający swój wizerunek jak aktorzy na scenie), wreszcie - łączy zwięzłe frazy oryginału w długie zdanie o dykcji pytajnej, upychając w nie pary synonimiczne: „ci a takowi”, „za lekkie a za pośmienie”, „się odmieniają a inakszy się ukazują”, „na duszy a na myśli”. $\mathrm{Z}$ jednej więc strony obserwujemy skłonność Anonima do banalizacji i upraszczania, odbywających się głównie za sprawą mniejszych i większych opustek czy odważnych zabiegów redukcyjnych, z drugiej strony - do substytucji. Te ostatnie przyjmują postać amplifikacji leksykalnych i redundancji znaczeniowych, sygnalizowanych (uwaga ta dotyczy całego przekładu) przez obecność naddanych objaśnień (explanatio) ${ }^{30}$ oraz przede wszystkim przez pary semantyczne (obecność dookreślających słów lub wyrażeń zestawianych paralelnie, ściślej - stosowanie dwóch aspektów znaczeniowych dla jednego łacińskiego wyrazu, który - być może - wydawał się tłumaczowi nazbyt

starcy, to młodzieńcy, to rumiani, to bladzi, to grubi, to wysmukli. A przecież do ludzi tego rodzaju zaliczają się ci, których mowa jest w sprzeczności z usposobieniem. I nikt się istnieniu tego rodzaju aktorów nie dziwi, nikt ich nie wygwizduje".

29 Erazm z Rotterdamu *Anonim, Księgi, IV 33, s. 112.

30 Przykładów amplifikacji na poziomie językowym, wynikłych z chęci objaśniania zwięzłych zwrotów oryginału albo z zamiaru zrekompensowania pominiętych w przekładzie passusów, w pracy Anonima jest wiele; jeden z bardziej wyrazistych zob. ibidem, V 35 oraz ibidem, Objaśnienia, s. 642. 
wieloznaczny ${ }^{31}$ ) lub przez ciągi synonimiczne (łączenie współrzędnym spójnikiem „a” lub „„” leksemów o identycznym bądź bardzo zbliżonym sensie oraz takie ich namnażanie, że płyną w zdaniu procesyjnym niemal rytmem) ${ }^{32}$. Niekiedy zaś można odnieść wrażenie (świadczą o tym liczne w tłumaczeniu przykłady), że tego rodzaju parami rządzi stylistyczna figura hendiadys ${ }^{33}$, albo wzmacniająca znaczenie,

31 Zdarzało się tłumaczowi wprowadzać do tekstu polskiego dwa aspekty semantyczne jednego wyrazu łacińskiego, jak np. w odniesieniu do słowa superat, które przekłada jako „przewycięża i przewyższa” (Erasmus Roterodamus, Lingua 1526, k. 77ver.; Erazm z Rotterdamu *Anonim, Księgi, IV 117, s. 132); aspekty semantyczne łacińskiego wyrazu impietas wyraża z kolei potrójnym szeregiem wyrazowym: „niesłusznym, złym a nieprzystojnym” (Erasmus Roterodamus, Lingua 1526, k. 73ver.; Erazm z Rotterdamu *Anonim, Księgi, IV 92, s. 127).

32 Posługiwanie się tego rodzaju parami czy synonimicznymi szeregami (niektórzy badacze $\mathrm{w}$ pracach poświęconych m.in. synonimii w dawnych dziełach prozatorskich oraz $\mathrm{w}$ tłumaczeniach Biblii nazywają je - z czym trudno jednak się zgodzić - glosami, i przydają im objaśniającą, komentatorską funkcję, niekiedy też przypisują średniowieczny rodowód; zob. np. S. Hrabec, Język Bazylika w przektadzie Andrzeja Frycza Modrzewskiego, Warszawa 1953; K. Górski, Biblia $i$ sprawy biblijne $w$ "Postylli" Reja, w: idem, $Z$ historii i teorii literatury, seria 1, Wrocław 1959, s. 7-60; E. Belcarzowa, O tzw. glosach w Biblii Leopolity, w: Studia historycznojezzkowe i dialektologiczne, red. M. Kucała, J. Reichan, Kraków 1992, s. 43-53; M. Leńczuk, Staropolskie przekazy kanonu Mszy Świętej. Wariantywność leksykalna, Warszawa 2013) uznać wypada za bardzo charakterystyczną cechę stylu nie tylko przekładowej literatury dawnej czy staropolskiej prozy (zob. np. K. Siekierska, Funkcje synonimów w języku „Pamiętników” J. Ch. Paska, „Poradnik Językowy”, 5, 1976, s. 229-238), ale i piśmiennictwa łacińskiego w ogóle; synonimia - warto też o tym pamiętać - uwzględniana była w kompendiach retorycznych i określana niekiedy mianem perysologii, m.in. przez H. Lausberga (idem, Retoryka literacka. Podstawy wiedzy o literaturze, tł. A. Gorzkowski, Bydgoszcz 2002, s. 296-297, 368-371). W tłumaczeniu dzieła Lingua tak silnie te szeregi się uobecniają, że uznać je wypada za swoistą manierę translatorską Anonima. Zwróciła na ów fakt uwagę M. Karplukówna (eadem, "Lingua” Erazma z Rotterdamu w polskim przektadzie, s. 127-129), jakkolwiek nadwyżki takie tłumaczy ona zwłaszcza nieporadnością leksykalno-stylistyczną staropolskiego pisarza, niekiedy też traktuje je jako formę komentarza do przekładanego tekstu. Szeregom synonimicznym ostatnio również M. Piasecka (eadem, „Lingua” Erazma z Rotterdamu w staropolskim przektadzie. Warsztat pracy ttumacza w XVI wieku, Warszawa 2017, s. 41-70) poświęciła w swej książce wiele miejsca, przypisując im perswazyjną i dydaktyczną funkcję w dziele, podkreślając zarazem, że oferują one czytelnikowi szeroką perspektywę wyboru i pozwalają mu „próbować się” ze znaczeniami.

33 „Upodobanie do wyrażania jednego pojęcia dwoma wyrazami” na materiale Postylli Reja z figurą hendiadys łączy K. Górski (idem, Biblia i sprawy biblijne $w$ „Postylli” Reja, s. 41); jednoznacznie krytyczne zaś stanowisko - trudno 
albo odwrotnie - intensyfikująca nie tyle semantykę, ile zwłaszcza zawarty w słowach ładunek emocjonalny ${ }^{34}$ (np. loquaces, w przekładzie: „mowni a żwawi” ${ }^{35}$; magnis clamoribus, w przekładzie: „się [--] swarzą a wołają" 36 ; armis lub quam fortiter [--] provocavit, w przekładzie: „walką a mocą” i „jako go wzburzył a pobudził”37). Warto przy okazji powyżej przywołanego przykładu przymiotnika loquaces odnotować jeszcze jeden sposób posługiwania się przez tłumacza szeregami synonimicznymi, łączonymi nie spójnikiem „a”, lecz „albo”, otóż rzeczownik loquacitas, oddany przez Anonima jako „mowa albo żwawość”" ${ }^{38}$, pokazuje, że kojarzenie słów za pomocą spójnika „albo” wskazywać może już nie tyle na możliwość dokonania semantycznego wyboru, prawem wzajemnego wykluczania się wyrazów, ile do rozszerzenia znaczeń używanych słów. Tak czy inaczej, szeroko pojęta synonimia (też synonimia geminująca) zarówno w pracy Polaka, jak i w ogóle w humanistycznej prozatorskiej tradycji przekładowej okazała się skuteczna m.in. jako sposób na przełamanie oczywistej nieadekwatności używanych w łacinie i w polszczyźnie słów czy pojęć, jest też rodzajem estetycznej i semantycznej varietas ${ }^{39}$.

Upodobanie do dramatu wyraża się u Erazma też poprzez odniesienia bądź cytaty z komedii Plauta i Terencjusza. A warto pamiętać, że Rotterdamczyk był jednym z pierwszych pisarzy doby wczesnonowożytnej w Europie (drugim, niemal pół wieku później, był Justus Lipsjusz), którzy mieli odwagę i w szczególny sposób potrafili - znalazłszy się na drodze ucieczki przed nudnym puryzmem włoskich cyceronianistów - wykorzystać potencjał rzymskiej fabula palliata, z jej pikantnym realizmem, potoczną, kolokwialną, skrzącą się archaizmami,

jednak na ów radykalizm przystać - wobec sposobu rozumienia tej retorycznej figury w odniesieniu do szeregów synonimicznych zajęła M. Piasecka (eadem, op. cit., s. 54-55).

34 Zob. Erazm z Rotterdamu *Anonim, Księgi, Objaśnienia, s. 396.

35 Erasmus Roterodamus, Lingua 1526, k. 17ver. („wielomówni”); Erazm z Rotterdamu *Anonim, Księgi, I 72, s. 56.

36 Erasmus Roterodamus, Lingua 1526, k. 43rec. („z wielkim krzykiem”); Erazm z Rotterdamu *Anonim, Ksieggi, III 76, s. 89.

37 Erasmus Roterodamus, Lingua 1526, k. 48rec. („orężem” lub „jak mężnie zaczepiał”); Erazm z Rotterdamu *Anonim, Księgi, III 115, s. 96.

38 Erasmus Roterodamus, Lingua 1526, k. 14ver. (ita loquacitatis vitium - „tak wada gadulstwa"); Erazm z Rotterdamu *Anonim, Ksiegi, I 53, s. 53.

$39 \mathrm{Na}$ temat synonimii w humanistycznej tradycji przekładowej zob. F. Tateo, Przektad, upowszechnienie, wybory językowe w prozie humanistycznej, tł. M. Wojtkowska-Maksymik, OiRwP, 53, 2009, s. 19-23. 
pełną ekspresji łaciną ${ }^{40}$. W przekładzie dzieła Lingua niewiele pozostało z Plautowych i Terencjuszowych dialogów, wobec których staropolski tłumacz najwyraźniej zachowywał trwożliwą rezerwę, zwłaszcza że bohaterami tych komediowych scen byli franci i stręczyciele (niezmiennie Anonim określa ich jako błaznów), jak np. w obrazującym pogardę dla hipokryty dynamicznym fragmencie zbudowanym z Terencjuszowych fraz Formiona (Phorm. 525-526):

In comoediis exsibilatur ille qui audit: "Non pudet vanitatis?” ac respondet: "Non, dum ob rem”, dicitur enim a lenone et applauditur ei, quod mox sequitur: "Sterquilinium”. At in hominum vita, quam multi sunt qui Dorionem superant vanitate, "dum ob rem”, cum Platonum et Catonum personam gerant ${ }^{2+1}$.

Redukcje i przestrojenia semantyczne oraz retoryczne (w oryginale ostatnie zdanie pytajne), jakich dokonał Anonim, sprawiły, że tekst polski - pozbywszy się konotacji sytuacyjnych - chwieje się na granicy zrozumienia:

Żadny się nie wstydzi próżnych rzeczy czynić. I wiele tych, co chcą, aby je miano za Platona, za Katona i na postawie poważnymi się być ukazują, ale uczynki ty czynią, że też Doryjona onego błazna przewyciężają ${ }^{42}$.

Warto zwrócić uwagę na fakt, iż usunięcie znacznej części oryginalnego passusu spowodowało, iż stręczyciel Dorion, który jest bohaterem tej sceny, przestaje być w pracy Anonima figurą i potrzebną, i czytelną w świetle logiki tego, co z wywodu Rotterdamczyka w przekładzie ocalało ${ }^{43}$.

40 Szerzej na ten temat zob. J. Dąbkowska-Kujko, Erazmianizm i lipsjanizm w Rzeczypospolitej, w: Wśród krajów Pótnocy. Kultura Pierwszej Rzeczypospolitej wobec narodów germańskich, stowiańskich $i$ naddunajskich: mapa spotkań, przestrzenie dialogu, red. M. Hanusiewicz-Lavallee, Warszawa 2015, s. 267-268 (Kultura Pierwszej Rzeczypospolitej w Dialogu z Europą. Hermeneutyka Wartości, t. 1); eadem, Justus Lipsjusz i dawne przektady jego dziet na jezyk polski, Lublin 2010, s. $109-142$.

${ }^{41}$ Erasmus Roterodamus, Lingua 1526, k. 52rec. Tł. „W komediach wygwizdywany jest ten, kto słyszy: „Czy nie wstyd ci takiej nieuczciwości?«, a on odpowiada: »Nie, póki to korzystne«, wypowiada to bowiem stręczyciel [Dorion], a publiczność przyklaskuje temu określeniu, które wnet następuje: „Dół kloaczny«. A w ludzkim życiu, ilu jest takich, co Doriona przewyższają nieuczciwością, "póki to korzystne", chociaż noszą maskę Platonów czy Katonów?” (tł. J.D.-K., W. Kopek).

${ }^{42}$ Erazm z Rotterdamu *Anonim, Ksieggi, III 137-138, s. 101.

43 Por. ibidem, Objaśnienia, s. 435. 
W miejscu zaś, gdzie Erazm zwięźle zestawia biblijnego faryzeusza z mnichami splamionymi oszczerstwem, a tych ostatnich aluzyjnie z Terencjuszowym pasożytem Formionem (Pharisaeus enim tantum peccat arrogantia, isti Phormiana malitia ${ }^{44}$; tł.: „Faryzeusz bowiem grzeszy jedynie pychą, owi zaś - złośliwością typową dla Formiona”), redukcja wzmianki do komediowego bohatera dokonana przez Anonima skutkuje - dość paradoksalnie - amplifikacją o semantycznych konsekwencjach: „abowiem on lucemiernik tym jedno grzeszył, że się $\mathrm{z}$ tego podnosił a chlubił z dobrych uczynków, ale ci, miasto modlenia, złorzeczą językiem, mówiąc a modląc się w kościele" 45 .

Wyraźnie widać tu tendencję staropolskiego tłumacza do „uzupełniania” oryginału przez dopowiadanie treści mu obcych, abundantnego omawiania znaczeń łacińskich słów, owocującego w powyżej przywołanym passusie zamianą rzeczowników w odpowiadające im formy czasownikowe („grzeszył, że się z tego podnosił a chlubił z dobrych uczynków”), „hendiadycznego” generowania wyrazów połączonych współrzędnym spójnikiem i wreszcie - do stałych uników wobec antycznej tradycji literackiej, komediowej i satyrycznej zwłaszcza ${ }^{46}$.

Nie można nie zauważyć, że choć finalnie otrzymujemy w translacji odmienny od pierwotnego fragment, to zarazem taki, który - paradoksalnie - nie odstępuje od głównego toku myśli oryginału. Dzieje się tak dlatego, że Anonim bardzo ostrożnie zbiera z dzieła Erazma wszystkie ważne ideowo sygnały, a wsłuchując się w nie, konkretyzuje cytaty, przekuwając je we własne frazy zawierające wychowawczy ton słyszalny u Rotterdamczyka $\mathrm{z}$ teatralnej sceny oraz z kart rzymskich satyryków. I choć nie ma w polskim tekście ani oratio recta, ani przekład ów nie zaprasza czytelnika do intertekstualnej gry, ani nie kieruje do odbiorcy pytań, nie operuje kontrastem, cytatem i układem ich powtórzeń, porządkujących i zarazem dynamizujących wypowiedź, to przekaz pozostaje z jednej strony taki sam, z drugiej wszelako - odmienny. Ambiwalencja rozciąga się na granicy tego, co proponuje treść, i tego, co oferuje estetyczna, retoryczna i polikulturowa tkanka dzieła, nieobojętna przecież i doktrynalnie, i emocjonalnie; ambiwalencja ta wyznacza oś konstrukcyjną pracy Anonima, nazbyt często naznaczając ją piętnem dosłowności. Retardacje

${ }^{44}$ Erasmus Roterodamus, Lingua 1526, k. 89ver.

45 Erazm z Rotterdamu *Anonim, Księgi, IV 174, s. 147.

46 Por. ibidem, Objaśnienia, s. 600. 
syntaktyczno-leksykalne tłumacza, uzyskiwane dzięki frazom tkanym z redundantnych wyrażeń i leksemów, amplifikują dzieło i wyhamowują jego ekspresję, nie próbując przy tym wprowadzić myśli obcej podstawie łacińskiej. Tajemnica tłumaczenia kryje się więc nie tyle w różnicach w zakresie treści rozumianej najpłycej i najdosłowniej, lecz w obszarach głębszych - poziomu dowodzenia i kultury myśli, w rewirach subtelności retoryki i meandrach gry dziełami autorów starożytnych, w dziedzinie sztuki dowodzenia i ekspozycji słowa uwikłanego w literacką tradycję i tej tradycji w pełni świadomego. Nie da się przy tym zaprzeczyć, że rozumienie oryginału przez Anonima nie ograniczało się wyłącznie do znajomości słownictwa i gramatyki, tj. wzajemnych zależności między słowami, ale dotyczyło również samego sensu zdań. Tłumacz niewątpliwie trafnie odczytywał właściwy desygnat tekstu, intencjonalnie przy tym rezygnując (powodowany złożonym zamysłem) z estetycznych, ekspresyjnych, obrazowych, retorycznych, a także erudycyjnych nadwyżek. Potrafił więc zarówno odwzorowywać sekwencje słów, jak i zaburzać w przekładzie ich porządek, a nawet dopowiadać (prawem amplifikacji leksykalnych i konkretyzacji semantycznych) od siebie całe człony.

Należy zarazem zauważyć, że opisane powyżej praktyki translacyjne w żadnym razie nie prowadzą do zafałszowań (co najwyżej nieznacznych przesunięć, a częściej - do neutralnych nadwyżek) znaczeniowych, że szeroko pojęte zabiegi redukcyjne Polaka (włączyć tu bowiem trzeba nie tylko drobniejsze pominięcia w obrębie poszczególnych wątków, ale i radykalne opustki znacznych fragmentów) są na tyle ostrożne, jeśli nie po prostu rozumne, iż oddają czy wręcz pielęgnują - mimo wszystko - zasadniczy tok wywodu, nie prowadząc ani do logicznych, ani kompozycyjnych dewastacji, że w końcu - nie tworzy on własnego dzieła, co najwyżej zabarwia oryginał kolorytem nie tylko własnej maniery językowej, ale i własnego wyobrażenia o możliwościach percepcyjnych czy nawet intelektualnych polskiego odbiorcy. Krótko mówiąc - skłonność z jednej strony do redukcji, uogólnień i uproszczeń, z drugiej - do konkretyzacji, amplifikacji i abundancji leksykalnych jest jedną z głównych cech maniery przekładowej Polaka.

Uproszczenia te zarazem nie zawsze są tak „niewinne”, jak należałoby sądzić z powyższych przykładów, za redukcjami bowiem podążają groźne banalizacje. Są one groźne nie tylko dlatego, że pozbawiają dzieło głębi, że degenerują odzwierciedlony w oryginale humanistyczny paradygmat kultury, że niekiedy zmieniają zauważalny w nim 
układ wartości czy aksjologiczną optykę, ale i dlatego, że samemu Erazmowi odbierają chwałę uczonego. Banalizacje i redukcje, o jakich tu mowa, mają zresztą różną naturę i wymuszane są przez złożone okoliczności; do najgłówniejszych należą: zachowania cenzorskie tłumacza (być może wyrosłe na gruncie puryzmu religijnego i obyczajowego), jego niedostatki erudycyjne, zamysł adaptacyjny, będący wyrazem przekonania, iż do niektórych problemów polski odbiorca jeszcze nie dorósł, swoiste zniecierpliwienie oraz instynkt pragmatyczny wreszcie, podpowiadający, że z punktu widzenia dydaktycznego przewrotność i dosadność retoryczna, treści odsyłające do detali pogańskiej kultury i obyczajów, aluzje literackie, uwagi filozoficzne, dociekania etymologiczne i filologiczne są czytelnikowi po prostu niepotrzebne. Tak oto większość passusów wybudowanych w oryginale łacińskim na podłożu erudycyjnym pierzcha z przekładu jak senne majaki ${ }^{47}$.

\section{Bibliografia}

\section{Źródła}

Bruni L., O poprawnym przektadaniu, tł. W. Olszaniec, w: Cyceron, św. Hieronim, Burgundiusz z Pizy, Leonardo Bruni, O poprawnym przektadaniu. Teksty tacinsskie i przektady polskie, tł. W. Seńko, J. Domański, W. Olszaniec, wstęp J. Domański, Kęty 2006

Desiderius Erasmus Roterodamus, Lingua. Opus novum et hisce temporibus aptissimum, Basileae 1525

Desiderius Erasmus Roterodamus, Lingua. Opus novum et hisce temporibus aptissimum, Cracoviae 1526

Erazm z Rotterdamu *Anonim, Księgi, które zowa Język, wyd. J. Dąbkowska-Kujko, Warszawa 2019

Erazm z Rotterdamu, Pisma moralne. Wybór, tł. i oprac. M. Cytowska, Warszawa 1970

Erazm z Rotterdamu, Pochwata gtupoty, tł. E. Jędrkiewicz, Warszawa 2001

Księgi, które zowa Język, z tacińskiego na polski wytożony, Kraków 1542

Lipsius I., De constantia libri duo, qui alloquium praecipue continent in publicis malis, Antverpiae 1584

Lipsius I., Politicorum, sive Civilis doctrinae libri sex, qui ad principatum maxime spectant, Lugduni Batavorum 1589

47 Fakt pomijania erudycyjnych partii dzieła Erazma przez Anonima tłumaczony jest przez M. Piasecką (eadem, op. cit., s. 79 nn.) nie tyle względami percepcyjnymi i intelektualnymi odbiorcy, z którymi musiał się liczyć Polak, ile oceną dydaktycznej przydatności danego ustępu. 
Marlianus A., Theatrum politicum, in quo quid agendum sit a principe et quid cavendum accurate praescribitur, Romae 1631

Saavedra D. F. E., Idea principis christiano-politici centum symbolis expressa, Amstelodami 1651

Vives L., O podawaniu umiejętności, tł., wstęp i przyp. A. Kempfi, Wrocław 1968

\section{Opracowania}

Belcarzowa E., O tzw. glosach w Biblii Leopolity, w: Studia historycznojezykowe i dialektologiczne, red. M. Kucała, J. Reichan, Kraków 1992, s. 43-53

Christian L. G., Theatrum mundi. The History of an Idea, New York-London 1987

Curtius E. R., Literatura europejska i tacińskie średniowiecze, th. i oprac. A. Borowski, Kraków 1997

Dąbkowska-Kujko J., Erazmianizm i lipsjanizm w Rzeczypospolitej, w: Wśród krajów Pótnocy. Kultura Pierwszej Rzeczypospolitej wobec narodów germańskich, stowiańskich i naddunajskich: mapa spotkań, przestrzenie dialogu, red. M. Hanusiewicz-Lavallee, Warszawa 2015 (Kultura Pierwszej Rzeczypospolitej w Dialogu z Europą. Hermeneutyka Wartości, t. 1), s. 247-287

Dąbkowska-Kujko J., Justus Lipsjusz i dawne przektady jego dziet na jezyk polski, Lublin 2010

Dąbkowska-Kujko J., „Lingua” Erazma z Rotterdamu a diatryba, w: Stawa $z$ dowcipu sama wiecznie stoi... Prace ofiarowane Pani Profesor Alinie Nowickiej-Jeżowej z okazji pięćdziesięciolecia pracy naukowej, red. M. Hanusiewicz-Lavallee, W. Pawlak, Lublin 2018, s. 57-68

Dąbkowska-Kujko J., Wprowadzenie do lektury, w: Erazm z Rotterdamu *Anonim, Księgi, które zowa Język, wyd. J. Dąbkowska-Kujko, Warszawa 2019, s. 5-29

Górski K., Z historii i teorii literatury, seria 1, Wrocław 1959

Hrabec S., Jezzyk Bazylika w przektadzie Andrzeja Frycza Modrzewskiego, Warszawa 1953

Karplukówna M., Erazm w Polsce: „Lingua” w anonimowym przekładzie z 1542 r., "Język Polski”, 84, 2004, 1, s. 1-9

Karplukówna M., „Lingua” Erazma z Rotterdamu w polskim przektadzie z roku 1542. Część I, „Pamiętnik Literacki”, 62, 1971, 1, s. 119-141

Karplukówna M., „Lingua” Erazma z Rotterdamu w polskim przektadzie z roku 1542. Część II, „Pamiętnik Literacki”, 62, 1971, 2, s. 97-113

Kąkolewski I., Melancholia wtadzy. Problem tyranii w europejskiej kulturze politycznej XVI stulecia, Warszawa 2007

Kąkolewski I., W poszukiwaniu "makiawelskiego momentu”. Metafora księcia jako wielkiego symulanta i aktora u Niccolò Machiavellego i Tomasza Morusa, „Przegląd Historyczny”, 96, 2005, 2, s. 305-325 
Kotarska J., Topos "theatrum mundi” w poezji przetomu XVI i XVII wieku, w: Przetom wieków XVI i XVII w literaturze i kulturze polskiej, red. B. Otwinowska, J. Pelc, Wrocław 1984, s. 145-169

Kotarska J., Theatrum mundi. Ze studiów nad poezją staropolska, Gdańsk 1998

Lausberg H., Retoryka literacka. Podstawy wiedzy o literaturze, tł. A. Gorzkowski, Bydgoszcz 2002

Leńczuk M., Staropolskie przekazy kanonu Mszy Świętej. Wariantywność leksykalna, Warszawa 2013

Marinelli L., Polski „Adon”. O poetyce i retoryce przektadu, tł. L. Marinelli, A. Nowicka-Jeżowa, współudz. Z. Ożóg, Izabelin 1997

Piasecka M., „Lingua” Erazma z Rotterdamu w staropolskim przektadzie. Warsztat pracy ttumacza $w$ XVI wieku, Warszawa 2017

Siekierska K., Funkcje synonimów w jezyku „Pamiętników” J. Ch. Paska, „Poradnik Językowy”, 5, 1976, s. 229-238

Szmydtowa Z., O Erazmie i Reju, Warszawa 1972

Sznajderman M., Btazen. Maski i metafory, Gdańsk 2000

Tateo F., Przektad, upowszechnienie, wybory jezykowe w prozie humanistycznej, tł. M. Wojtkowska-Maksymik, OiRwP, 53, 2009, s. 13-26

\section{Old-Polish Translation of Erasmus' Lingua in the "Mirror of Theatre" of Prototype (The Case of One Plot)}

The article is devoted to the humanistic culture of language and thought presented on the example of translation strategies of an anonymous translator of Erasmus' Lingua. The features characteristic of translation have been exposed and focused mainly on one topic - theatre or acting and hypocrisy associated with it. An analysis of the methods adopted by the Old Polish author of Books that are called Language (Ksiag, które zowia Jezzyk) to transpose the original into the native cultural environment leads to a somewhat paradoxical conclusion: on the one hand, it reveals a translator who, not being interested in the humanistic cultural paradigm of the original, employing his characteristic techniques of reduction and simplification, amplification and in particular abundance, redirects the reader's attention from the world of values to the world of "happening", limiting his work to the presentation of the original's content on the shallowest, because fictional and didactic, level. Thus, he rejects the erudite fabric of the work and assumes the role of a kind of censor who transforms and rejects those aspects that - in his opinion - are unsuitable for the Polish reader. On the other hand, he translates with care and prudence, remaining faithful to the work's main ideas, 
not depriving it of its ideological message at any point. And this message is the thought about language, which is the touchstone of the deepest values of humanitas. According to the Dutch humanist, it is the language that is responsible for interpersonal bonds and relations, and perhaps especially for the ethical quality of these relations, because language is - in the light of the author's assumptions - the guarantor of Christian standards of communication. It is the language that shapes and reflects the axiological aspects of the human spirit.

Dr hab Justyna Dąbkowska-Kujko - prof. Katolickiego Uniwersytetu Lubelskiego Jana Pawła II; zatrudniona w Katedrze Literatury Staropolskiej KUL. Zainteresowania badawcze: literatura polskiego i europejskiego renesansu i baroku, edytorstwo dzieł literatury dawnej.

Justyna Dąbkowska-Kujko - PhD with habilitation, professor of the John Paul II Catholic University of Lublin; employed at the Department of Old Polish Literature of the Catholic University of Lublin; research interests: literature of the Polish and European Renaissance and Baroque, editing of the old literature.

E-mail: justdab@kul.pl 